\title{
Impact of High Density Planting and Weed Management Practices on Yield Attributes, Yield and Quality Characters of Bt Cotton
}

\author{
B. Madavi ${ }^{1}$, P. Leela Rani ${ }^{2 *}$, G. Sreenivas ${ }^{3}$, A. Madhavi ${ }^{4}$ and K. Surekha ${ }^{5}$ \\ ${ }^{1}$ Department of Agronomy College of Agriculture, Professor Jayashankar Telangana State \\ Agricultural University, Rajendranagar, Hyderabad, Telangana, India \\ ${ }^{2}$ AICRP on Weed Management, Professor Jayashankar Telangana State Agricultural University, \\ Rajendranagar, Hyderabad, Telangana, India \\ ${ }^{3}$ Agro Climate Research Centre, ARI, Professor Jayashankar Telangana State Agricultural \\ University, Rajendranagar, Hyderabad, Telangana, India \\ ${ }^{4}$ STCR, ARI, Professor Jayashankar Telangana State Agricultural University, Rajendranagar, \\ Hyderabad, Telangana, India \\ ${ }^{5}$ Indian Institute of Rice Research, Rajendranagar, Hyderabad, Telangana, India \\ *Corresponding author
}

\section{A B S T R A C T}

\begin{tabular}{l}
\hline K e y w o r d s \\
Bt cotton, HDPS, \\
Weed control, \\
Yield and quality \\
characters. \\
\hline Article Info \\
\hline $\begin{array}{l}\text { Accepted: } \\
\text { 04 June } 2017 \\
\text { Available Online: } \\
\text { 10 August } 2017\end{array}$ \\
\hline
\end{tabular}

\section{Introduction}

Cotton (Gossypium hirsutum L.), the 'white gold' or 'money spinner' enjoys a predominant position among all cash crops in India and cultivated since Indus civilization. Cotton is the livelihood for an estimated 60 million Indians including 6 million farmers, mostly small and marginal. Cotton cropping provide $60 \%$ of the fibre used in Indian textile industries, supplies more than one million metric ton of cooking oil and another million metric ton of quality animal feed and 40 million metric tons of biomass in the form of cotton stalks. Global demand for cotton consumption continues to grow and was 
driven by the fiber demands of the fast growing world economies like India and China and the growing world population. It is estimated that, the global demand for cotton will be about 48 million metric tons by 2030 against from current levels of 25 million metric tons. However, considering the issues pertaining to food security and land pressures, the global area under cotton cultivation will largely be constant at the current levels of 34 million hectares (FICCI, 2012).

Almost 95 per cent Indian cotton farmers are being used the genetically modified $\mathrm{Bt}$ cotton. But the farmers facing the problem of stagnating yields from Bt cotton hybrids due to increased labour demand, increased labour costs, increased seed costs, and increased costs for cotton picking and nutrient requirements. All these facts point to the dire need for sustainable practices. So, to sustain the productivity, high density planting systems, with narrow and ultra-narrow spacing for rainfed soils and developing suitable management options for improving yields and also to improve input use efficiency is the need of hour. The concept on high density cotton planting, more popularly called Ultra Narrow Row (UNR) cotton was initiated by Briggs et al., (1967). In general, lower plant densities produces high values of growth and yield attributes per plant, but yield per unit area was higher with higher plant densities (Sharma et al., 2001).

However, moderate increase in plant densities may not increase the yield but decrease due to competition between plants for nutrients, water, space and light (Nehra and Kumawat, 2003).

Optimum cotton yield and quality for highdensity planting cotton requires good weed control throughout the growing season. The weeds can severely decrease cotton productivity and can negatively affect the lint quality. A number of weed species infest the cotton field includes such as Cynodon dactylon (L.) Pers., Trianthema portulacastrum L., Convolvolus arvensis L., Cyperus rotundus L., Conyza canadensis L. and Sorghum halepense (L.) Pers. can be quoted as the most important examples (Kalivas et al., 2012; Dogan et al., 2014). Four plants of $E$. indica in one meter row of cotton crop were found to decrease number of bolls per plant by $25 \%$ and the cotton yield by $>20 \%$ (Xiao-Yan et al., 2015). HDPS will provide a soil canopy in about 30 days as compared to 60-75 days for conventional row widths, which will shade out weeds and reduce their competitiveness. In view of the above, present research work carried out with the objective to find out the effect of High Density Planting System (HDPS) and weed management practices on on yield and quality of Bt cotton.

\section{Materials and Methods}

A field experiment was conducted during kharif, 2015 at College farm, College of Agriculture, Professor Jayashankar Telangana State Agricultural University, Rajendranagar, Hyderabad. The farm is geographically situated at an altitude of $542.6 \mathrm{~m}$ above mean sea level on $18^{\prime} 50^{\circ} \mathrm{N}$ latitude and $77.53^{\circ} \mathrm{E}$ longitude The soil of the experimental field was sandy loam in texture, low in available $\mathrm{N}$ $\left(250 \mathrm{~kg} \mathrm{ha}^{-1}\right)$, medium in phosphorus $(21.68$ $\left.\mathrm{kg} \mathrm{P}_{2} \mathrm{O}_{5} \mathrm{ha}^{-1}\right)$ and high in potassium $(685.6 \mathrm{~kg}$ $\mathrm{K}_{2} \mathrm{O} \mathrm{ha}^{-1}$ ).

The experiment was conducted to test the impact of four planting densities 55,555 plants $\mathrm{ha}^{-1}(60 \mathrm{~cm} \times 30 \mathrm{~cm}), 1,11,111$ plants ha ${ }^{-1}(60$ $\mathrm{cm} \times 15 \mathrm{~cm})$ normal planting, 1,11,111 plants $\mathrm{ha}^{-1}(60 \mathrm{~cm} \times 15 \mathrm{~cm})$ paired row planting, $1,48,148$ plants ha ${ }^{-1}(45 \mathrm{~cm} \times 15 \mathrm{~cm})$ and weed management practices viz., pendimethalin 1.0 $\mathrm{kg} \mathrm{ha} \mathrm{h}^{-1}$ as pre emergence fb pyrithiobac sodium $62.5 \mathrm{~g} \quad \mathrm{ha}^{-1}+$ quizalofop-p-ethyl $50 \mathrm{~g}$ $\mathrm{ha}^{-1}$ at 20, 40, 60, DAS, pyrithiobac sodium $62.5 \mathrm{~g} \mathrm{ha}^{-1}+$ quizalofop-p-ethyl $50 \mathrm{~g} \mathrm{ha}^{-1}$ at 15 
DAS as early post emergence fb glyphosate ammonium salt $2.13 \mathrm{~kg} \mathrm{ha}^{-1}$ at $45 \mathrm{DAS}$, pendimethalin $1.0 \mathrm{~kg} \mathrm{ha}^{-1}$ as pre emergence $\mathrm{fb}$ HW at 20 and 45 DAS and unweeded control on yield and quality of $B t$ cotton in randomized block design (factorial), replicated thrice. The crop was sown on $26^{\text {th }}$ June. Other cultural operations and plant protections measures were followed as per the recommendations. During the crop period rainfall of $404.3 \mathrm{~mm}$ was received in 28 rainy days in 2015 as against the decennial average of $683.1 \mathrm{~mm}$ received in 35 rainy days for the corresponding period. Yield variables include average number of bolls (opened) per plant and unit area, average boll weight. Average boll weight was calculated by dividing the total plant seed cotton yield with respected number of bolls of the plant. Kapas yield per hectare $\left(\mathrm{kg} \mathrm{ha}^{-1}\right)$. Stalk yield $\left(\mathrm{kg} \mathrm{ha}^{-1}\right)$ and harvest index was computed from cotton yield per plot and the data were subjected to statistical analysis and interpretation. Average ginning per cent was calculated treatment wise for four pickings using following formula (Khan et al., 2010).

$$
\begin{gathered}
\text { Lint yield (Fibre) } \\
\text { Ginning }(\%)=--\mathbf{S e d} \text { cotton yield (Fibre+ Seeds) }
\end{gathered}
$$

The ginning percent alone does not convey any idea about the total production of fibres hence; lint index was calculated to overcome this drawback by using the following formula given by Panse and Sukhatme (1967).

Weight of 100 seeds $x$ ginning per cent Lint index -

$$
100 \text { - Ginning per cent }
$$

Seed index ensures evaluation of types with properly developed seeds and leads to development of lint index. It was worked out by taking weight of 100 seeds $(\mathrm{g})$ from each net plot after ginning.

\section{Results and Discussion}

\section{Yield parameters}

\section{Effect of plant densities}

Number of opened bolls per plant, average boll weight and seed cotton yield per plant and hectare were significantly influenced by planting density. Cotton planted at 55,555 plants ha ${ }^{-1}$ in wide rows $(60 \mathrm{~cm} \mathrm{x} 30 \mathrm{~cm})$ produced more bolls per plant (Table 1). As plant density increased by decreasing intra row and inter row spacing, number of opened bolls per plant decreased as observed in plant density of 1,11,111 plants ha ${ }^{-1}(60 \mathrm{~cm} \times 15$ $\mathrm{cm})$ normal planting and was significantly superior over 1,11,111 plants ha ${ }^{-1}(60 \mathrm{~cm} \times 15$ $\mathrm{cm})$ paired row planting, in turn this was on par with $1,48,148$ plants $\mathrm{ha}^{-1}(45 \mathrm{~cm} \times 15 \mathrm{~cm})$ density.

Reduced cotton plant densities typically produce a greater number of bolls outside the first and second position as well as sympodia arising from monopodial branches that may be due to less inter plant competition between cotton plants (Stephenson et al., 2011). However, cotton planted with plant density of $1,11,111$ plants ha ${ }^{-1}(60 \mathrm{~cm} \times 15 \mathrm{~cm})$ normal planting produced more bolls $\mathrm{m}^{-2}$ and proved to be superior over rest of the plant density. This was followed by $1,48,148$ plants $\mathrm{ha}^{-1}(45$ $\mathrm{cm} \times 15 \mathrm{~cm}$ ), this in turn on par with $1,11,111$ plants $\mathrm{ha}^{-1}(60 \mathrm{~cm} \times 15 \mathrm{~cm})$ paired row planting. Significantly less number of bolls $\mathrm{m}^{-}$ ${ }^{2}$ was obtained with 55,555 plants ha ${ }^{-1}(60 \mathrm{~cm}$ $\mathrm{x} 30 \mathrm{~cm})$ treatment. The results are in conformity with results of Dong et al., (2010), where high plant density increased the number of bolls per unit area relative to low plant densities.

Average boll weight was increased with plant density of 55,555 plants $\mathrm{ha}^{-1}$, and was comparable with $1,11,111$ plants $\mathrm{ha}^{-1}$ normal 
and paired row planting, which in turn on par with $1,48,148$ plants ha $^{-1}$. Reductions in plant to plant spacing decreased boll weight due to intense competition for nutrients, water and light at higher plant density (Ogola et al., 2006).

However, Bednarz et al., (2000) accredited decreased boll set and weight due to combined effect of excessive LAI, reduced PPFD (photosynthetic photon flux density) efficiency and reduced mean NAR at higher plant population.

The present results were in conformity with results of Dong et al., (2010), where high plant density reduced the boll weight relative to low plant density.

\section{Effect of weed management practices}

More number of boll plant ${ }^{-1}$, number of boll $\mathrm{m}^{-2}$ and average boll weight was recorded with pre emergence application of pendimethalin $1.0 \mathrm{~kg} \mathrm{ha}^{-1} \mathrm{fb}$ PoE tank mix application of pyrithiobac sodium $62.5 \mathrm{~g}$ ha ${ }^{1}$ +quizalofop-p-ethyl $50 \mathrm{~g} \mathrm{ha}^{-1}$ at 20, 40, 60 DAS and was on par with pendimethalin 1.0 $\mathrm{kg} \mathrm{ha}^{-1}$ (PE) fb HW at 20 and 45 DAS and early PoE tank mix application of pyrithiobac sodium $62.5 \mathrm{~g} \mathrm{ha}^{-1}+$ quizalofop-p-ethyl $50 \mathrm{~g}$ $\mathrm{ha}^{-1}$ at 15 DAS fb directed spray of glyphosate ammonium salt $2.13 \mathrm{~kg} \mathrm{ha}^{-1}$ at 45 DAS.

These were significantly superior over unweeded control treatment (Table 1). Bolls plant $^{-1}$ was lowest with the unweeded control. This might be due to reduced crop dry matter and increased weed competition as the weeds are allowed freely to compete with cotton plants (Madhu et al., 2014). The increased number of bolls $\mathrm{m}^{-2}$ might be due to more weed control efficiency with reduced weed dry matter during critical period of crop weed competition. The reduced boll weight might be due to reduced availability of water, light and nutrients to cotton crop, thereby reduced
LAI and crop dry matter leads to the poor portioning of resource to sink (bolls).

\section{Kapas yield (g plant $\left.{ }^{-1}\right)$}

\section{Effect of Plant densities}

Cotton planted at 55,555 plants $\mathrm{ha}^{-1}$ with wider spacing $(60 \mathrm{~cm} \times 30 \mathrm{~cm})$ recorded more kapas yield per plant and was proved superior over rest of the plant densities (Table 1). This was followed by $1,11,111$ plants ha ${ }^{-1}(60 \mathrm{~cm}$ $\mathrm{x} 15 \mathrm{~cm}$ ) normal and paired row planting, plant density of $1,48,148$ plants $\mathrm{ha}^{-1}(45 \mathrm{~cm} \mathrm{x}$ $15 \mathrm{~cm})$, recorded the lowest kapas yield plant ${ }^{-}$ ${ }^{1}$. Cotton plant produced more bolls plant ${ }^{-1}$ in wider rows because of substantial space available for growth, more photosynthetic efficiency, frequent availability of water and nutrients, less humidity for efficient control of insect pest attack and boll saving from rottening, which resulted in increase in fruiting points, fruiting period, fruit retention and ultimately greater bolls plant ${ }^{-1}$ and seed cotton yield plant ${ }^{-1}$ (Munir et al., 2015).

However, more kapas yield ha ${ }^{-1}$ was observed with plant density of $1,11,111$ plants ha $^{-1}$ (60 $\mathrm{cm} \times 15 \mathrm{~cm}$ ) normal planting and was proved superior over rest of the plant densities under study (Table 1). This was followed by 11111 plants $\mathrm{ha}^{-1}(60 \mathrm{~cm} \times 15 \mathrm{~cm})$ paired row planting, 1,48,148 plants $\mathrm{ha}^{-1}(45 \mathrm{~cm} \mathrm{x} 15 \mathrm{~cm})$ and 55,555 plants $\mathrm{ha}^{-1}(60 \mathrm{~cm} \times 30 \mathrm{~cm})$, in turn these two were on par with each other.

More number of bolls $\mathrm{m}^{-2}$, boll weight might have increased the yield in 1, 11,111 plants $\mathrm{ha}^{-1}$ normal planting over rest of the densities. Yield increase of $30.31 \%, 29.57 \%$ and 17.20 $\%$ was observed when plant density was increased to $1,11,111$ plants $\mathrm{ha}^{-1}$ normal planting from plant density of 55,555 plants $\mathrm{ha}^{-1}, 1,48,148$ plants $\mathrm{ha}^{-1}$ and 11111 plants ha ${ }^{-1}$ paired row planting respectively. 
Table.1 Yield attributes and yield of Bt cotton under varied plant densities and weed management practices during kharif, 2015

\begin{tabular}{|c|c|c|c|c|c|c|c|}
\hline \multirow{2}{*}{$\begin{array}{l}\text { Treatment } \\
\text { Plant densities (D) }\end{array}$} & \multicolumn{7}{|c|}{ Yield attributes and yield } \\
\hline & $\begin{array}{c}\text { Boll No. } \\
\text { plant }^{-1}\end{array}$ & $\begin{array}{c}\text { Boll No. } \\
\mathrm{m}^{-2}\end{array}$ & $\begin{array}{c}\text { Boll } \\
\text { weight } \\
(\mathrm{g})\end{array}$ & $\begin{array}{l}\text { Kapas } \\
\text { yield }(g \\
\left.\text { plant }^{-1}\right)\end{array}$ & $\begin{array}{c}\text { Yield } \\
\left(\mathrm{Kg} \mathrm{ha}^{-1}\right)\end{array}$ & $\begin{array}{l}\text { Stalk } \\
\text { yield } \\
\left(\mathrm{Kg} \mathrm{ha}^{-1}\right)\end{array}$ & $\mathrm{HI}$ \\
\hline $60 \mathrm{~cm} \times 30 \mathrm{~cm}(55,555)$ & 12 & 66 & 5.20 & 64.00 & 2184 & 5,532 & 27.11 \\
\hline $60 \mathrm{~cm} \times 15 \mathrm{~cm}(1,11,111)$ & 10 & 116 & 5.20 & 53.83 & 3134 & 9,995 & 22.58 \\
\hline $60 \mathrm{~cm} \times 15 \mathrm{~cm}(1,11,111$ Paired row- $45 \mathrm{~cm} \times 75 \mathrm{~cm})$ & 8 & 90 & 4.89 & 41.75 & 2595 & 8,943 & 21.83 \\
\hline $45 \mathrm{~cm} \times 15 \mathrm{~cm}(1,48,148)$ & 7 & 100 & 4.71 & 35.92 & 2207 & 11,387 & 15.67 \\
\hline S. Em \pm & 0.50 & 4.17 & 0.14 & 2.62 & 149.43 & 379.43 & 1.92 \\
\hline $\mathrm{CD}(\mathrm{P}=0.05)$ & 1.46 & 12.12 & 0.41 & 7.60 & 433.69 & $1,101.19$ & 3.46 \\
\hline \multicolumn{8}{|l|}{ Weed Management Practices (W) } \\
\hline $\begin{array}{l}\text { Pendimethalin } 30 \% \text { EC } 1.0 \mathrm{~kg} \mathrm{ha}^{-1} \text { as PE fb PoE pyrithiobac } \\
\text { sodium } 62.5 \mathrm{~g} \mathrm{ha}^{-1}+\text { quizalofop-p-ethyl } 5 \% \text { EC } 50 \mathrm{~g} \mathrm{ha}^{-1} \text { at } 20,40 \text {, } \\
60 \text { DAS }\end{array}$ & 12 & 122 & 5.42 & 66.25 & 3119 & 11049 & 22.50 \\
\hline $\begin{array}{l}\text { Pyrithiobac sodium } 10 \% \text { EC } 62.5 \mathrm{~g} \mathrm{ha}^{-1}+\text { quizalofop-p-ethyl } 50 \mathrm{~g} \\
\text { ha }^{-1} \text { at } 15 \mathrm{DAS} \text { as early PoE fb glyphosate } 71 \% \mathrm{SG} 2.13 \mathrm{~kg} \mathrm{ha}^{-1} \text { at } \\
45 \text { DAS }\end{array}$ & 11 & 110 & 5.25 & 58.25 & 3018 & 9533 & 24.41 \\
\hline Pendimethalin $1.0 \mathrm{~kg} \mathrm{ha}^{-1}$ as PE fb HW at 20 and $45 \mathrm{DAS}$ & 12 & 116 & 5.16 & 60.83 & 3058 & 10222 & 24.00 \\
\hline $\mathrm{W}_{4}$-Unweeded control & 2 & 24 & 4.18 & 10.17 & 925 & 5054 & 16.33 \\
\hline S. Em \pm & 0.50 & 4.17 & 0.14 & 2.62 & 149.43 & 379.43 & 1.92 \\
\hline $\mathrm{CD}(\mathrm{P}=0.05)$ & 1.46 & 12.12 & 0.41 & 7.60 & 433.69 & $1,101.19$ & 3.38 \\
\hline \multicolumn{8}{|l|}{ Interaction (D X W) } \\
\hline S. Em \pm & 1.01 & 8.35 & 0.28 & 5.24 & 298.87 & 758.87 & 2.46 \\
\hline $\mathrm{CD}(\mathrm{P}=0.05)$ & NS & NS & NS & NS & NS & NS & NS \\
\hline
\end{tabular}


Table.2 Qualitative characters in Bt cotton under varied plant densities and Weed management practices kharif, 2015

\begin{tabular}{|c|c|c|c|}
\hline Treatment & $\begin{array}{l}\text { Lint } \\
\text { index }\end{array}$ & $\begin{array}{c}\text { Ginning } \\
\%\end{array}$ & $\begin{array}{c}\text { Seed } \\
\text { index }(g)\end{array}$ \\
\hline \multicolumn{4}{|l|}{ Plant densities (D) } \\
\hline $60 \mathrm{~cm} \times 30 \mathrm{~cm}(55,555)$ & 9.21 & 33.84 & 10.42 \\
\hline $60 \mathrm{~cm} \times 15 \mathrm{~cm}(1,11,111)$ & 12.02 & 37.54 & 10.33 \\
\hline $60 \mathrm{~cm} \times 15 \mathrm{~cm}(1,11,111$ Paired row- $45 \mathrm{~cm} \times 75 \mathrm{~cm})$ & 8.71 & 34.37 & 9.92 \\
\hline $45 \mathrm{~cm} \times 15 \mathrm{~cm}(1,48,148)$ & 7.81 & 33.74 & 8.08 \\
\hline S. Em \pm & 1.42 & 2.85 & 0.881 \\
\hline $\mathrm{CD}(\mathrm{P}=0.05)$ & NS & NS & NS \\
\hline \multicolumn{4}{|l|}{ Weed Management Practices $(\mathrm{W})$} \\
\hline $\begin{array}{l}\text { Pendimethalin } 30 \% \text { EC } 1.0 \mathrm{~kg} \mathrm{ha}^{-1} \text { as PE fb PoE pyrithiobac sodium } 62.5 \mathrm{~g} \\
\text { ha }^{-1}+\text { quizalofop-p-ethyl } 5 \% \text { EC } 50 \mathrm{~g} \mathrm{ha}^{-1} \text { at } 20,40,60 \text { DAS }\end{array}$ & 11.60 & 42.73 & 11.08 \\
\hline $\begin{array}{l}\text { Pyrithiobac sodium } 10 \% \text { EC } 62.5 \mathrm{~g} \mathrm{ha}^{-1}+\text { quizalofop-p-ethyl } 50 \mathrm{~g} \mathrm{ha}^{-1} \text { at } 15 \\
\text { DAS as early PoE fb glyphosate } 71 \% \mathrm{SG} 2.13 \mathrm{~kg} \mathrm{ha}^{-1} \text { at } 45 \text { DAS }\end{array}$ & 10.49 & 38.25 & 11.33 \\
\hline Pendimethalin $1.0 \mathrm{~kg} \mathrm{ha}^{-1}$ as PE fb HW at 20 and 45 DAS & 9.67 & 40.86 & 10.50 \\
\hline Unweeded control & 5.98 & 17.66 & 5.83 \\
\hline S. Em \pm & 1.42 & 2.85 & 0.881 \\
\hline $\mathrm{CD}(\mathrm{P}=0.05)$ & NS & 8.29 & 2.56 \\
\hline \multicolumn{4}{|l|}{ Interaction (D X W) } \\
\hline S. Em \pm & 2.84 & 5.71 & 1.761 \\
\hline $\mathrm{CD}(\mathrm{P}=0.05)$ & NS & NS & NS \\
\hline
\end{tabular}

Even though, the boll number, boll weight and seed cotton yield plant ${ }^{-1}$ was significantly higher with wider spacing, it could not compensate for the loss in number of plants $\mathrm{ha}^{-1}$ and number of bolls $\mathrm{m}^{-2}$, thus recorded lower seed cotton yield ha $^{-1}$ when compared to high density planting. Higher plant density at closer spacing recorded significantly higher seed cotton yield than lower plant density at wider spacing due to significantly more number of bolls $\mathrm{m}^{-2}$ and higher plant stand $\mathrm{ha}^{-1}$ (Brar et al., 2013).

\section{Stalk yield ( $\left.\mathrm{kg} \mathrm{ha}^{-1}\right)$}

In variance to the kapas yield, significantly higher stalk yield was recorded with $1,48,148$ plants ha ${ }^{-1}(45 \mathrm{~cm} \times 15 \mathrm{~cm})$ over rest of the plant densities (Table 1). The increased stalk yield at higher density might be due to increased plant population per unit area (Dong et al., 2012). This was followed by $1,11,111$ plants $\mathrm{ha}^{-1}(60 \mathrm{~cm} \times 15 \mathrm{~cm})$ normal planting and paired row planting and were on par with each other. Significantly lower stalk yield was observed with plant density of 55,555 plants ha ${ }^{-1}(60 \mathrm{~cm} \times 30 \mathrm{~cm})$.

\section{Effect of weed management practices}

Significantly more kapas yield plant ${ }^{-1}$, kapas yield $\mathrm{ha}^{-1}$ and stalk yield $\mathrm{ha}^{-1}$ was recorded with pre emergence application of pendimethalin $1.0 \mathrm{~kg} \mathrm{ha}^{-1} \mathrm{fb}$ PoE tank mix application of pyrithiobac sodium $62.5 \mathrm{~g} \mathrm{ha}^{-}$ +quizalofop-p-ethyl $50 \mathrm{~g} \mathrm{ha}^{-1}$ at 20, 40, 60

DAS and was on par with pendimethalin 1.0 $\mathrm{kg} \mathrm{ha}^{-1}$ (PE) fb HW at 20 and 45 DAS, which in turn on par with early PoE tank mix application of pyrithiobac sodium $62.5 \mathrm{~g} \mathrm{ha}^{-1}$ + quizalofop-p-ethyl $50 \mathrm{~g} \mathrm{ha}^{-1}$ at $15 \mathrm{DAS} \mathrm{fb}$ directed spray of glyphosate ammonium salt $2.13 \mathrm{~kg} \mathrm{ha}^{-1}$ at 45 DAS treatments (Table 1). The lowest kapas yield plant ${ }^{-1}$ was observed with unweeded control treatment. The reduced kapas yield plant ${ }^{-1}$ might be due to 
poor contribution of harvested bolls, boll weight and seed cotton yield per plant in unweeded control treatment. Similar findings showed that the cotton yield was reduced by 50 to 80 per cent with unchecked weed growth in $\mathrm{Bt}$ cotton (Rajendra and Jain, 2004). The increased kapas yield plant $^{-1}$ in other treatments might be due to timely and effective control of weeds by herbicides coupled with cultural methods which resulted in better availability of soil moisture and nutrients. Similar results were reported by Singh et al., (2004) and Gnanavel and Babu (2008) who showed that application of pendimethalin or fluchloralin $1.0 \mathrm{~kg} \mathrm{ha}^{-1} \mathrm{fb}$ one hand weeding at 45 DAS produced significantly higher seed cotton yield. The increased kapas yield due to occurrence of less competition between cotton plants and weeds leading to more number of bolls and resulted in higher seed cotton yield (Madhu et al., 2014). Further, timely and effective control of weeds through herbicides coupled with cultural methods which resulted in better availability of soil moisture and nutrients (Prabhu et al., 2012). Presence of weeds throughout the growing season caused poor crop growth and caused reduced leaf area index and crop dry matter resulted in reduced stalk yield over other weed management practices

\section{Harvest index (\%)}

\section{Effect of Plant densities}

Higher harvest index value $(27.11 \%)$ was noticed with 55,555 plants $\mathrm{ha}^{-1}$ followed by $1,11,111$ plants $\mathrm{ha}^{-1}$ normal planting and paired row planting. The lowest harvest index was recorded with 1,48,148 plants $\mathrm{ha}^{-1}$. High plant density produced the greatest biological yield but the lowest harvest index (Table 1). Although high plant density increase total plant biomass per unit ground area (biological yield), final reproductive allocation as indicated by harvest index was usually reduced by increased plant density because of luxurious vegetative growth and lower lint yield (Ali et al., 2009). The increased plant density delayed the leaf senescence due to improved leaf photosynthesis, but significantly reduced the boll load. There was a significant negative correlation $(\mathrm{r}=$ -0.8014 ) between boll load and leaf senescence at the onset of boll opening (Dong et al., 2012).

\section{Effect of weed management practices}

Higher harvest index was noticed with early PoE tank mix application of pyrithiobac sodium $62.5 \mathrm{~g} \mathrm{ha}^{-1}+$ quizalofop-p-ethyl $50 \mathrm{~g}$ $\mathrm{ha}^{-1}$ at 15 DAS fb glyphosate ammonium salt $2.13 \mathrm{~kg} \mathrm{ha}^{-1}$ at $45 \mathrm{DAS}$ and was followed by pendimethalin $1.0 \mathrm{~kg} \mathrm{ha}^{-1}$ (PE) fb $\mathrm{HW}$ at 20 and 45 DAS and pre emergence application of pendimethalin $1.0 \mathrm{~kg} \mathrm{ha}^{-1} \mathrm{fb}$ PoE tank mix application of pyrithiobac sodium $62.5 \mathrm{~g} \mathrm{ha}^{-}$ ${ }^{1}$ +quizalofop-p-ethyl $50 \mathrm{~g} \mathrm{ha}^{-1}$ at 20, 40, 60 DAS. The lowest harvest index value was recorded with unweeded control treatment due to reduced number of bolls, boll weight and kapas yield plant ${ }^{-1}$.

\section{Quality characters}

The quality characters viz., ginning percentage, lint index and seed index was not affected due to modification of plant densities (Table 2). However weed management practices exert significant influence on ginning percent and seed index. Higher ginning per cent was noticed with pre emergence application of pendimethalin 1.0 $\mathrm{kg} \mathrm{ha}{ }^{-1} \mathrm{fb}$ PoE tank mix application of pyrithiobac sodium $62.5 \mathrm{~g} \mathrm{ha}^{-1}+$ quizalofop-pethyl $50 \mathrm{~g} \mathrm{ha}^{-1}$ at 20, 40, 60 DAS and was on par with pendimethalin $1.0 \mathrm{~kg} \mathrm{ha}^{-1}$ (PE) fb HW at 20 and 45 DAS and early PoE tank mix application of pyrithiobac sodium $62.5 \mathrm{~g}$ $\mathrm{ha}^{-1}+$ quizalofop-p-ethyl $50 \mathrm{~g} \mathrm{ha}^{-1}$ at 15 DAS 
$\mathrm{fb}$ directed spray of glyphosate ammonium salt $2.13 \mathrm{~kg} \mathrm{ha}^{-1}$ at 45 DAS and were significantly superior over unweeded control treatment. But higher seed index values were obtained with early PoE tank mix application of pyrithiobac sodium $62.5 \mathrm{~g} \mathrm{ha}^{-1}+$ quizalofopp-ethyl $50 \mathrm{~g} \mathrm{ha}^{-1}$ at 15 DAS fb directed spray of glyphosate ammonium salt $2.13 \mathrm{~kg} \mathrm{ha}^{-1}$ at 45 DAS, pre emergence application of pendimethalin $1.0 \mathrm{~kg} \mathrm{ha}^{-1} \mathrm{fb}$ PoE application of pyrithiobac sodium $62.5 \mathrm{~g} \mathrm{ha}^{-1}+$ quizalofopp-ethyl $50 \mathrm{~g} \mathrm{ha}^{-1}$ at 20, 40, 60 DAS and pendimethalin $1.0 \mathrm{~kg} \mathrm{ha}^{-1}$ (PE) $\mathrm{fb} \mathrm{HW}$ at 20 and 45 DAS. The lower seed index values were recorded with unweeded control. Interaction effect of plant densities and weed management practices did not exert any significant influence on any of these parameters.

In conclusion, growing $\mathrm{Bt}$ cotton at plant density of $1,11,111$ plants $\mathrm{ha}^{-1}$ normal planting by adopting spacing of $60 \mathrm{~cm} \mathrm{x} 15$ $\mathrm{cm}$, without significant effect on lint index, ginning $\%$ and seed index was found to be effective to get significantly higher kapas yield $\left(3134 \mathrm{~kg} \mathrm{ha} \mathrm{ha}^{-1}\right)$ pre emergence application of pendimethalin $1.0 \mathrm{~kg} \mathrm{ha}^{-1} \mathrm{fb}$ PoE tank mix application of pyrithiobac sodium $62.5 \mathrm{~g} \mathrm{ha}^{-1}+$ quizalofop-p-ethyl $50 \mathrm{~g}$ $\mathrm{ha}^{-1}$ at 20, 40, 60 DAS.

\section{References}

Ali, A., M. Tahir, M. Ayub, I. Ali, A. Wasaya and Khalid, F. 2009. Studies on the Effect of Plant Spacing on Yield of Recently Approved Cotton Varieties. Pakistan Journal of Life and Social Science. 7 (1): 25-30.

Brar, A.S., R.S. Sarlach, R.S. Sohu and Rathore, P. 2013. Response of American cotton (Gossypium hirsutum L.) Genotypes to Varying Plant Densities and Graded Levels of Fertilizers. Society for Plant Research.
26 (2): 145-147.

Brar, J.S., B.S. Sidhu, K.S. Sekhon and Buttar, G.S. 2008. Responce of Bt Cotton (Gossypium hirsutum L.) to Plant Geometry and Nutrient Combinations in Sandy Loam Soil. Journal of Cotton Research and Development. 22 (1): 59-61.

Briggs, R.E., L.L. Patterson and Massey, G.D. (1967). Within and Between Row Spacing of Cotton. - Arizona Annual Report. P. 6-7. Univ. of Arizona Agric. Ext. Service, Arizona

Bednarz, C.W., D.C. Bridges and Brown, S.M. 2000. Analysis of Cotton Yield Stability across Population Densities. Agronomy Journal. 92: 128-135.

Dongan, M.N., K. Jabran and Unay, A. 2014. Integrated Weed Management in Cotton. Recent Advances in Weed Management, Chauhan, B.S and Mahajan, G. The Netherlands, Springer, Pp. 197-222.

Dong, H., X. Kong, W. Li, W. Tang and Zhang, D. 2010. Effects of Plant Density and Nitrogen and Potassium Fertilization on Cotton Yield and Uptake of Major Nutrients in Two Fields with Varying Fertility of Cotton Raised on a Saline Field. Field Crops Research. 119: 106-113.

Dong, H., W. Li, A.E. Eneji and Zhang, D. 2012. Nitrogen Rate and Plant Density Effects on Yield and Late Season Leaf Senescence of Cotton Raised on a Saline Field. Field Crops Research. 126: 137-144.

FICCI, 2012. Cotton 2020 Road Map for Sustainable Production. Agriculture Division. Federation house, Tansen Marg, New Delhi 110001, India.

Gnanavel, I and Babu, S. 2008. Integrated Weed Management in Irrigated Hybrid Cotton. Agriculture Science Digest. 28: 93-96.

Kalivas, D.P., C.E. Vlachos, G. Economou 
and Dimou, P. 2012. Regional Mapping of Perennial Weeds in Cotton with the Use of Geostatistics. Weed Sci. 60(2): 233-243.

Madhu, G., K. Srinivasulu, P.P. Rani and Rao, A.S. 2014. Economics of Rainfed $B t$ cotton as Influenced by Sequential Application of Herbicides. Journal of Cotton Research and Development. 28 (2): 257-259.

Munir, M.K., M. Tahir, M.F. Saleem and Yaseen, M. 2015. Growth, Yield and Earliness Response of Cotton to Row Spacing and Nitrogen Management. The Journal of Animal \& Plant Sciences. 25 (3): 729-738.

Nehra, P.L and Kumawat, P.D. 2003. Response of Hirsutum Cotton Varieties to Spacing and Nitrogen Levels. $J$. Cotton Res. Dev. 17 (1): 41-42.

Ogola, A.H., R.M. Opondo, G. Omuga and Malaya, H. 2006. The Effect of Plant Density and Soil Fertility Regimes on Seed Cotton (Gossypium hirstum L.) Yield.p.4. in Proc.10 ${ }^{\text {th }}$ KARI Biennial Scientific Conf. Nairobi. 12-17 Nov.2006. KARI Headquarters, Kaptagat Road, Loresho, Nairobi, Kenya. Online available at www.kari.org.

Panse, V.G and Sukhatme, P.V. 1967. Statistical Methods for Agricultural Workers (1st Ed.), ICAR, New DelhiI (India).

Prabhu, G., A.S. Halepyati, B.T. Pujari and Desai, B.K. 2012.Weed Management in Bt Cotton (Gossypium hirsutum L.) under irrigation. Karnataka Journal of Agriculture Science. 25 (2): 183-186.
Rajendra, T.P and Jain, K.C. 2004. Achievements in cotton research in the All India Coordinated Cotton Improvement Project. CICR Regional Station, Coimbatore, Tamil Nadu.

Sharma, J.K., Upadhayay, Mishra, S.K. Khamparia and Andloi, K.C.M. 2001.Effect of Spacing and Fertility Levels on Growth and Yield of Hirsutum Genotypes. J. Cotton Res. Dev.15 (2): 151-153.

Singh, P. 2004. Cotton Breeding. Kalyani Publishers, New Delhi, India. Pp. 295.

Singh, S and Singh, M. 2004. Effect of growth stage on trifloxysulfuron and glyphosate efficacy in twelve weed species of citrus groves. Weed Science Society of America-Weed Technology. 18: 1031-1036.

Srinivasulu, G and Rao, A.S. 2000. Effect of Sequential Application of Herbicides on Weed Management in cotton. In: Proceedings of Symposium on Challenges in Agronomic Crop Management in Early 21st Century Organized by Society of Agronomists, Hyderabad, May, 24-25. Pp. 71-74.

Stephenson, D.O., L.T. Barber and Bourland F.M. 2011. Effect of Twin Row Planting Pattern and Plant Density on Cotton Growth, Yield, and Fiber Quality. The Journal of Cotton Science. 15: 243-250.

Xiao-Yan, M.A, W.U. Han-Wen, J. Wei-Li, M.A. Ya-Jie and Yan, M.A. 2015: Goosegrass (Eleusine indica) Density Effects on Cotton (Gossypium hirsutum). J. Integr. Agric. 14:17781785.

\section{How to cite this article:}

Madavi, B., P. Leela Rani, G. Sreenivas, A. Madhavi and Surekha, K. 2017. Impact of High Density Planting and Weed Management Practices on Yield Attributes, Yield and Quality Characters of Bt Cotton. Int.J.Curr.Microbiol.App.Sci. 6(8): 194-202.

doi: https://doi.org/10.20546/ijcmas.2017.608.027 